\title{
Computer aided structural analysis of newly developed railway bogie frame
}

\author{
Pavol Št’astniak ${ }^{1, *}$, Marián Moravčík ${ }^{2}$, Peter Baran ${ }^{1}$, Lukáš Smetanka $^{1}$ \\ ${ }^{1}$ University of Žilina, Faculty of Mechanical Engineering, Department of Transport and Handling \\ Machines, Univerzitná 8215/1, 01026 Žilina, Slovak Republic \\ ${ }^{2}$ Tatravagónka Inc., Štefánikova 887/53, 05801 Poprad, Slovak Republic
}

\begin{abstract}
The paper is part of the publication series, which describe the most significant and innovative research and development design solutions and computational procedures as part of European structural funds project. The object of this article is strength conditions assessment of new structure of rail bogie frame, which is characterized mainly by better dynamic properties while driving on the track, good operational properties and higher safety against derailment. For validation of the new structure design, there has been created a substitute simulation model. Results of calculations and prototype tests prove, that new structure of the bogie frame satisfies strength assessments.
\end{abstract}

Keywords: stress analysis, bogie frame, computer tools

\section{Introduction}

Indeed nowadays about 1.5 billion $\mathrm{t} / \mathrm{km}$ are transported in Europe by lorry at distances farther than $150 \mathrm{~km}$, conversely only 0.4 billion $\mathrm{t} / \mathrm{km}(20 \%)$ are transported by train, this entails important costs for fossil fuels. In the nearby future when transportation has to be more sustainable it seems quite clear that freight railways will win the mode choice more often.

For this to happen though, it is necessary that freight railways, apart from lowering their prices, significantly improve highly increase the quality of transportation. In that sense, quality standards such as reliability, flexibility, availability, cargo security and safety, punctuality, customisation, marketability, traceability, complementary servicing and time for transport among others have to be improved by railways as well.

Hence, freight rail transport has the challenge to become excellent and to gain in reputation. There are many actions to increase quality in freight rail transport; one of them is the optimisation of the current wagon fleet to improve availability, flexibility, marketability, commercial speed, cargo security and cost. This optimisation has to respond to the actual trends of transport demand and has to be in consonance with the required and feasible infrastructure upgrades.

University of Žilina and Tatravagónka Inc. Poprad jointly respond to these requirements

\footnotetext{
*Corresponding author: pavol.stastniak@fstroj.uniza.sk

Reviewers: Vladimir Dekýš, Petr Horyl
} 
by means of the European structural funds project with name "Development of two types of freight wagons with bogies for non-standard wheelbase or track wheelset, complying with the criteria for interoperability, environmental issues, safety and reliability", where developed, among other things, a new freight rail bogie type TVP 2009-R (Fig. 1) for "Russian" track gauge of $1520 \mathrm{~mm}$.

\section{Technical specification of new freight bogie}

The concept is derived from the bogie type TVP 2007, which has been certified under TSI and they are currently used on the EU tracks with track gauge of $1435 \mathrm{~mm}$. Designed bogie hence used:

- simplicity and reliability of friction damping by system Lenoir,

- reliability based on verified design solutions,

- real speeds increase by using bogie technology with a rigid frame,

- transition improving through curves with small radiuses for wheelset radial position ensuring.
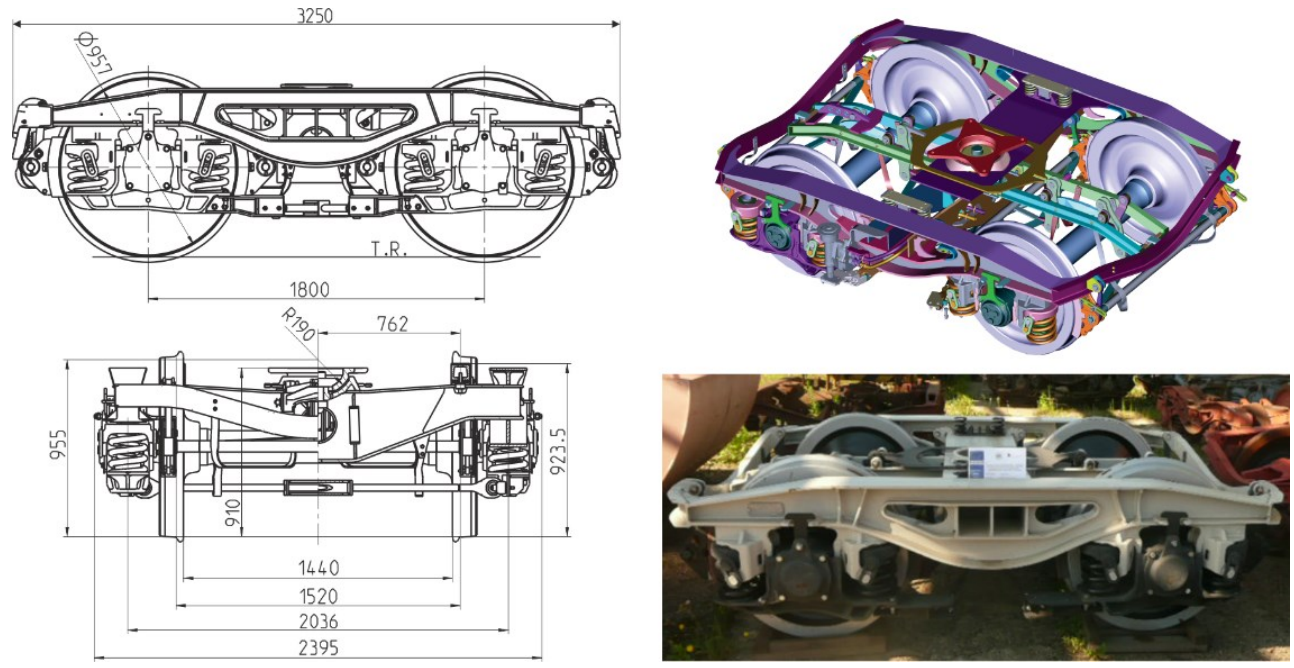

Fig. 1. The prototype of new railway bogie

The bogie type Y25 is characterized by wheelset guiding, in which is primary suspension with progressive damper as part of axlebox. The damper is always located on one side of the axlebox suspension of each wheelset. Bogies equipped with this standard configuration have a certain size of guiding forces while driving along the curve of the track and related technical consequences [1].

Table 1. Dimensional and technical parameters of the bogie

\begin{tabular}{|l|c|l|c|}
\hline Wheelbase & $1800 \mathrm{~mm}$ & $\begin{array}{l}\text { Height of the bogie pivot } \\
\text { above the top of rail }\end{array}$ & $900 \pm 12 \mathrm{~mm}$ \\
\hline Wheeldiameter & $957 \pm 7 \mathrm{~mm}$ & Weight & $4900 \mathrm{~kg} \pm 5 \%$ \\
\hline Axle pin diameter & $130 \mathrm{~mm}$ & $\begin{array}{l}\text { Maximum speed at an axle } \\
\text { load of } 25 \mathrm{t}\end{array}$ & $120 \mathrm{~km} / \mathrm{h}$ \\
\hline Axle pin length & $190 \mathrm{~mm}$ & Temperature range & $+50^{\circ} \mathrm{C}$ to $+60^{\circ} \mathrm{C}$ \\
\hline Lateral clearance of all axles & $\pm 10 \mathrm{~mm}$ & Special equipment & $\begin{array}{c}\text { ready fo Automatic } \\
\text { system MATROSOV }\end{array}$ \\
\cline { 1 - 2 } Longitudinal clearance of all axles & $\pm 8 \mathrm{~mm}$ & & composite brake blocks \\
\hline
\end{tabular}


In order to reduce these forces, the new design of bogie uses the connection of wheelsets by means of cross coupling. The purpose of cross coupling is radially adjustable wheelset position in curves. Therefore, the vehicle achieves better dynamic properties, higher safety against derailment and lower negative effect on the track, known as "track friendly" bogies. Basic technical and dimensional parameters of the bogie are listed in Table 1.

\section{Bogie frame assessment by means of computer simulations}

Every new freight bogie or wagon prototype before start in operation must be assessment and approval according to requirements of Technical Specifications for Interoperability (TSI). For assessing is authorized only notified body (NoBo). It is the organization responsible for the conformity assessment of interoperability constituents and structural subsystems as required in the TSI (in Europe e.g. Ricardo, Luxcontrol, Sconrail) and in Russian Federation only Federal Budgatery Organization "Register of Certification on the Federal Railway Transport".

As part of the documentation, which the applicant must submit, are the results of prototype tests. The aim of the validation plan is to prove that the design of the bogie frame fulfils the conditions defined in the technical specification. In addition, it shall show that the behaviour of the bogie frame, constructed according to the design, will give satisfactory service without the occurrence of defects such as catastrophic rupture, permanent deformation and fatigue cracks. It shall further demonstrate that there is no adverse influence on the associated bogie components or sub-assemblies.

The procedure for the validation of the mechanical strength of a bogie frame against the acceptance criteria shall be established on the basis of: 1) analysis (computations), 2) laboratory static tests, 3) laboratory fatigue tests, 4) track tests.

Currently, by using advanced computer technology is possible those tests at high levels predict by simulation analysis. The great advantage of the mentioned simulations is that the entire development process of rolling stock is so accelerated, leading to a reduction in overall costs. Simulations and subsequent optimization of the vehicle structure is made before production of the vehicle itself. This leads to minimizing the number of unsatisfactory results conducted on a real vehicle. This may, in such a stage of development lead to delays and increased costs. Computational models of vehicles and their components are more or less simplified compared with the actual ones. This simplification is seen when comparing the results from real tests.

The object of our calculations is the strength test of new design of freight bogie frame through FEM analysis.

\subsection{Computational model}

Computational model (Fig. 2) was created in program MSC.Marc. For analysis of bogie frame design by finite element method has been created mesh of shell finite elements, which lies in the planes center surfaces individual parts of analyzed design. The analysis is performed in a linear region. The distortion of the results of the analysis resulting from the introduction of the simplifications mentioned is considered negligible.

They are used as isoparametric, four-node shell elements with average size of elements $10 \mathrm{~mm}$. The thickness of the shell elements was determined according to the drawing documentation. Location of forces and boundary conditions (hemispherical bogie pivot, slides, etc.) are modeled by 2 -node beam elements. The springs of suspension are replaced with very soft beam elements. 


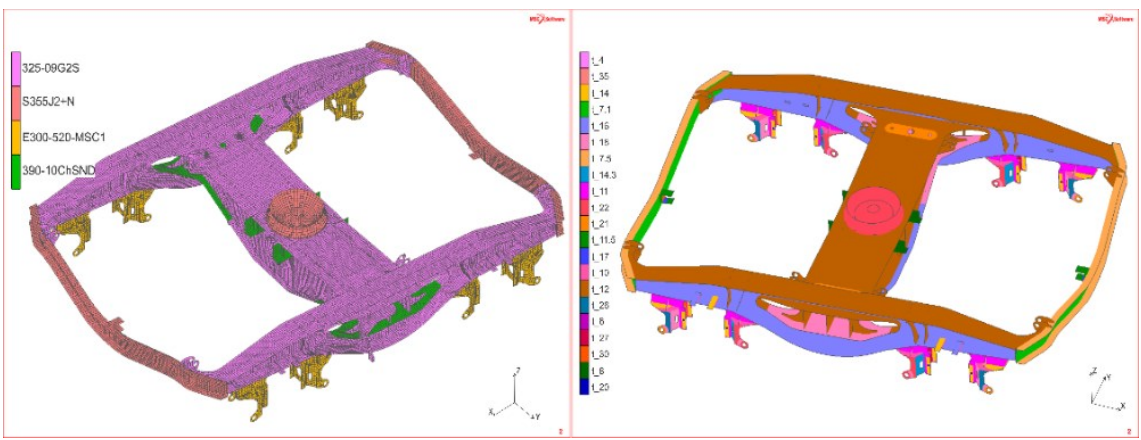

Fig. 2. Computational model - FEM mesh and elements thickness

Frame parts were designed from structural steel of 09G2S, 10ChSND, S355J2+N and their properties are shown in Table 2. Castings (axle guard) are designed of E300-520MSC1.

Table 2. Material properties

\begin{tabular}{|c|c|c|c|c|}
\hline \multirow{2}{*}{ Material } & \multirow{2}{*}{ Norm } & Thickness [mm] & Min. yield strength & Min. tensile strength \\
\cline { 3 - 5 } & & & Re [MPa] & Rm [MPa] \\
\hline 325-09G2S & GOST 19281-89 & from 10 to 20 & 325 & 450 \\
\hline 10ChSND & GOST 19281-89 & up to 40 & 390 & 510 \\
\hline E300-520-MSC1 & UIC 840-2 & casting & 300 & 520 \\
\hline S355J2+N & EN 10025-2 & up to 16 & 355 & 470 \\
\hline S355J2+N & EN 10025-2 & from 16 to 40 & 345 & 470 \\
\hline
\end{tabular}

Consideration is being given to the fact, that the material is linearly, elastic and isotropic. Mechanical properties: Young modulus of elasticity $\mathrm{E}=2.1 \cdot 10^{5} \mathrm{MPa}$, Poisson's ratio $\mu=0.3$. Goodman diagrams were used according [2], curves "a1", "a2", "b", annex F.3, with conditions of application of the annex F.4, safety factor 1.1.

\subsection{Boundary conditions}

Boundary conditions (Fig. 3) are captured:

- in the middle of lower flangeplate of transverse beam,

- in two nodes of lower flangeplate of transverse beam (exceptional loads),

- in the middle of manganese plates of axle guide (normal service loads),

- under 8 substitute springs.

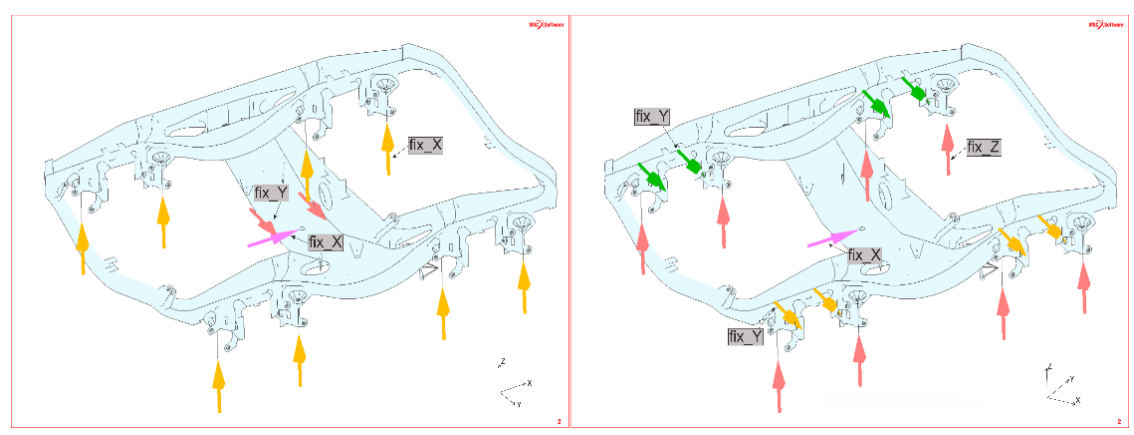

Fig. 3. Boundary conditions for exceptional loads (left) and normal service loads (right) 
The first two boundary conditions are used only for the stability of calculation, because reactions in them are practically zero.

\subsection{Load conditions}

In reality the loads are combined in a complex manner and so it is difficult to represent them exactly in analysis. Consequently, it is generally the practice, for ease of analysis, to represent the true loads by a series of load conditions which include the above effects in a simplified form, either individualy or in combination. It is essential that the simplification ensures that the effects of the true loads are not underestimated. The load conditions required for the design and assessment of the bogie frame will be depended on the application being considered.

The source data does not indicate how the specified loads should be reacted. Therefore, the designer needs to consider load balances appropriate to the application. In particular, the reactions to the lateral loads specified as acting at the wheelset should include the bogie inertia forces to determine realistic secondary suspension forces.

Load conditions were created according [3] for axle load $25 \mathrm{t}$. These are combinations of vertical loads in hemispherical bogie pivot, in slides, lateral forces in pivot and unevenness of the track. All loads used as the basis for the bogie design should incorporate any necessary allowance for uncertainties in their values. Schematic view of loading forces are shown in Fig. 4.

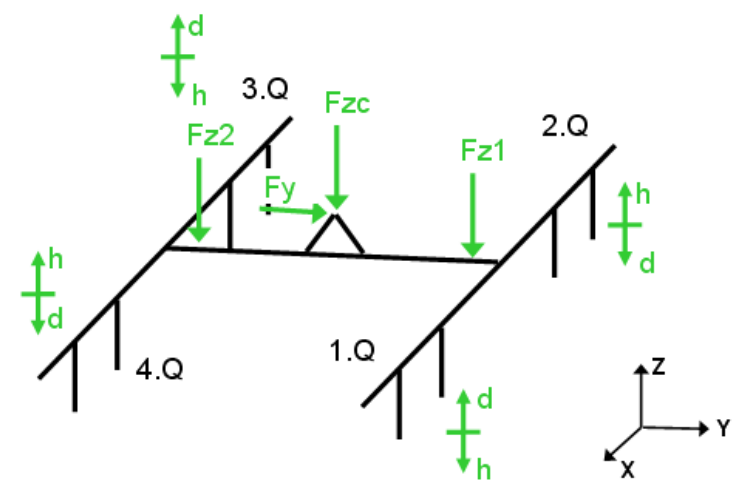

Fig. 4. Loading forces - schematic view

Loading conditions according [3] are divided into two groups (below). 


\section{A) Test under exceptional loads}

Table 3. Load cases for tests under exceptional loads

\begin{tabular}{|c|c|c|c|c|c|c|}
\hline \multirow{3}{*}{$\begin{array}{c}\text { Load } \\
\text { Condition }\end{array}$} & \multicolumn{3}{|c|}{ Vertical Forces $[\mathrm{kN}]$} & \multirow{3}{*}{$\begin{array}{l}\begin{array}{l}\text { Lateral } \\
\text { Forces }\end{array} \\
F_{y}[\mathrm{kN}]\end{array}$} & \multirow{3}{*}{$\begin{array}{c}\text { Unevennes } \\
\mathrm{s} \text { of track } \\
{[\% \text { ] }}\end{array}$} & \multirow{3}{*}{$\begin{array}{l}\text { Brake } \\
\text { Forces }\end{array}$} \\
\hline & $\begin{array}{c}\text { Sidebearer } \\
2\end{array}$ & $\begin{array}{c}\text { Hemispherical } \\
\text { bogie pivot }\end{array}$ & $\begin{array}{c}\text { Sidebearer } \\
1\end{array}$ & & & \\
\hline & $-F_{z 2}$ & $-F_{z c}$ & $-F_{z 1}$ & & & \\
\hline 1 & & 884.9 & & & & \\
\hline $2 \mathrm{~h}$ & & 464.6 & 199,1 & & 30 & \\
\hline $2 d$ & & 464.6 & 199,1 & & -30 & \\
\hline 3 & & 464.6 & 199,1 & 183.5 & & \\
\hline 4 & 199.1 & 464.6 & & -183.5 & & \\
\hline 5 & & 530.9 & & & & $F_{B}$ \\
\hline
\end{tabular}

According [4], annex J, counts with 1.2 times the braking forces. Longitudinal force in hemispherical bogie pivot and friction force between wheels and track are in balance during maximum braking.

\section{B) Test under normal service loads}

Table 4. Load cases for tests under normal service loads

\begin{tabular}{|c|c|c|c|c|c|}
\hline \multirow{2}{*}{$\begin{array}{c}\text { Load } \\
\text { Condition }\end{array}$} & \multicolumn{3}{|c|}{ Vertical Forces [kN] } & $\begin{array}{c}\text { Lateral } \\
\text { Forces } \\
{[\mathrm{kN}]}\end{array}$ & \multirow{2}{*}{$\begin{array}{c}\text { Unevenness of } \\
\text { track [\%o] }\end{array}$} \\
\cline { 2 - 4 } & $\begin{array}{c}\text { Sidebearer } \\
2\end{array}$ & $\begin{array}{c}\text { Hemispherical } \\
\text { bogie pivot }\end{array}$ & $\begin{array}{c}\text { Sidebearer } \\
1\end{array}$ & $F_{y}$ & \\
\cline { 2 - 5 } & $-F_{z 2}$ & $-F_{z c}$ & $-F_{z 1}$ & & \\
\hline 1 & & 442.4 & & & \\
\hline 2 & & 619.4 & & & \\
\hline 3 & & 265.5 & & & \\
\hline 4 & & 495.5 & 123.9 & 98.1 & \\
\hline 5 & 123.9 & 495.5 & & -98.1 & \\
\hline 6 & & 212.4 & 53.1 & 98.1 & \\
\hline 7 & 53.1 & 212.4 & & -98.1 & \\
\hline $4 \mathrm{~h}$ & & 495.5 & 123.9 & 98.1 & 15 \\
\hline $4 \mathrm{~d}$ & & 495.5 & 123.9 & 98.1 & -15 \\
\hline $5 \mathrm{~h}$ & 123.9 & 495.5 & & -98.1 & 15 \\
\hline $5 \mathrm{~d}$ & 123.9 & 495.5 & & -98.1 & -15 \\
\hline $6 \mathrm{~h}$ & & 212.4 & 53.1 & 98.1 & 15 \\
\hline $6 \mathrm{~d}$ & & 212.4 & 53.1 & 98,1 & -15 \\
\hline $7 \mathrm{~h}$ & 53.1 & 212.4 & & -98.1 & 15 \\
\hline $7 \mathrm{~d}$ & 53.1 & 212.4 & & -98.1 & -15 \\
\hline
\end{tabular}




\subsection{Evaluation of simulation}

The static strength requirements correspond to the exceptional load conditions under which the bogie shall remain fully functional. It shall be demonstrated by analysis and/or testing, that no permanent deformation, instability or fracture of the structure as a whole, or of any individual element, will occur under the exceptional design load conditions. It is important to ensure that the design loads are expressed in a form that is consistent with the method of analysis and the way in which the permissible material stress levels are defined.

\section{Exceptional loads}

Table 5. The highest values of von Mises stress and their position

\begin{tabular}{|l|c|c|c|c|}
\hline Place on the bogie frame & $\begin{array}{c}\text { Number of loading } \\
\text { condition }\end{array}$ & $\begin{array}{c}\text { Max. detected stress } \\
{[\mathrm{MPa}]}\end{array}$ & $\begin{array}{c}\text { Allowable stress } \\
{[\mathrm{MPa}]}\end{array}$ & Safety factor [-] \\
\hline Main transverse beam & 1 & 318 & 325 & 1.02 \\
\hline $\begin{array}{l}\text { Conection of mein transverse beam and } \\
\text { longitudinal beam }\end{array}$ & $1 \mathrm{~h}$ & 239 & 325 & 1.36 \\
\hline $\begin{array}{l}\text { Conection of mein transverse beam and } \\
\text { longitudinal beam }\end{array}$ & $1 \mathrm{~d}$ & 238 & 325 & 0.37 \\
\hline Upper flangeplate of longitudinal beam & 3 & 338 & 325 & 0.96 \\
\hline Upper flangeplate of longitudinal beam & 4 & 338 & 325 & 0.96 \\
\hline
\end{tabular}

The analysis is intended to detect the most critical places in the structure after axle load of 25 tons. We examined sizes of equivalent von Mises stress for all load conditions. The highest values, which were detected, are listed in Tab. 5. Some graphic behaviour of stresses on the undeformed bogie frame are shown in Fig. 5 and Fig. 6.

In load cases 3 and 4 was exceeded the permissible value. It is a place on the upper flangeplate of longitudinal beam (Fig. 6) with value of stress $338 \mathrm{MPa}$. Exceeding of permissible value about $4 \%$, but it is just in area 4 elements on upper sheet.

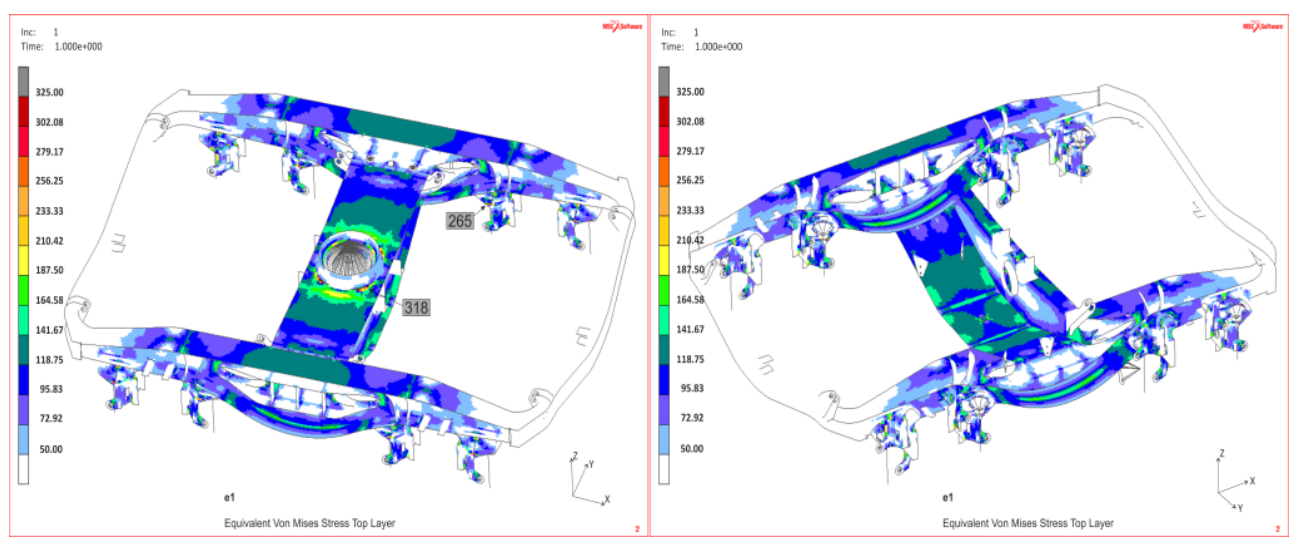

Fig. 5. Behaviour of von Mises stress for load condition no. 1 


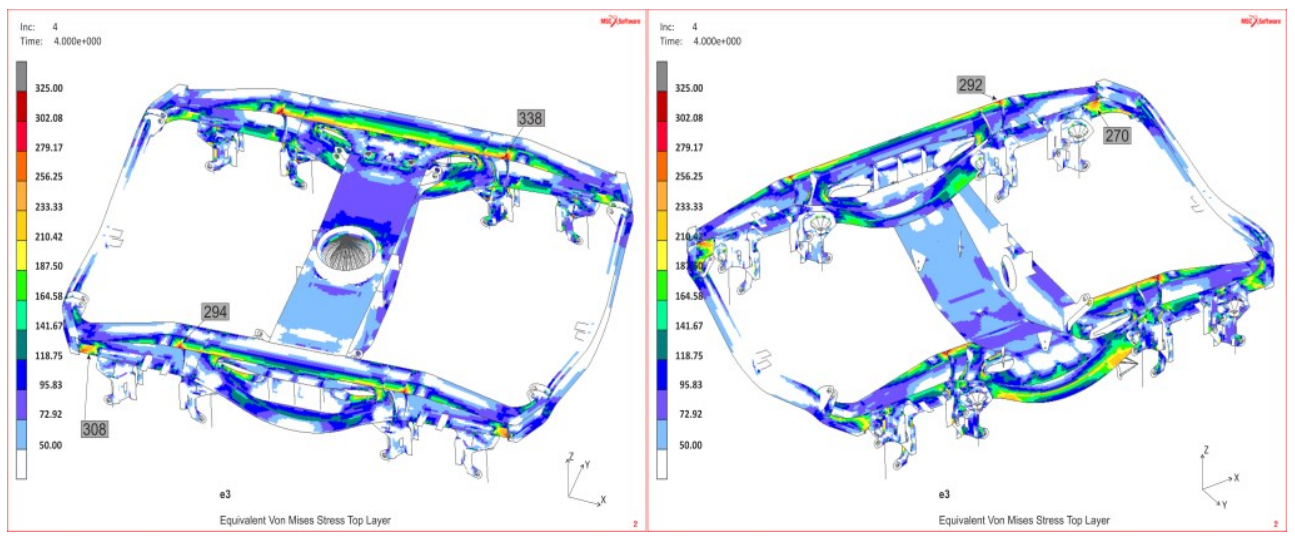

Fig. 6. Behaviour of von Mises stress for load condition no. 3

\section{Normal service loads}

For evaluation of simulation was used method according [4], annex J, point J.2. On the Fig. 7 and Fig. 8 are shown elements, which exceeded curves of Goodmans diagram (limit values for curves "a2", "a1" and "b" according [2], annex F.3, with safety factor 1.1).

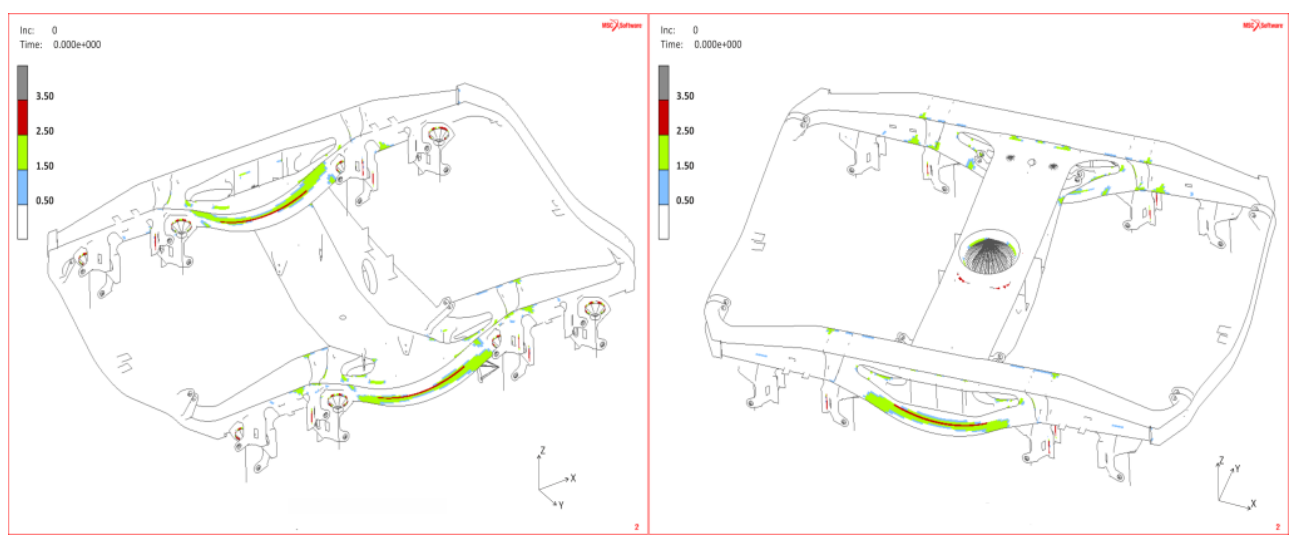

Fig. 7. Exceeded curve "b" (red color) - lower flangeplate of longitudinal beam

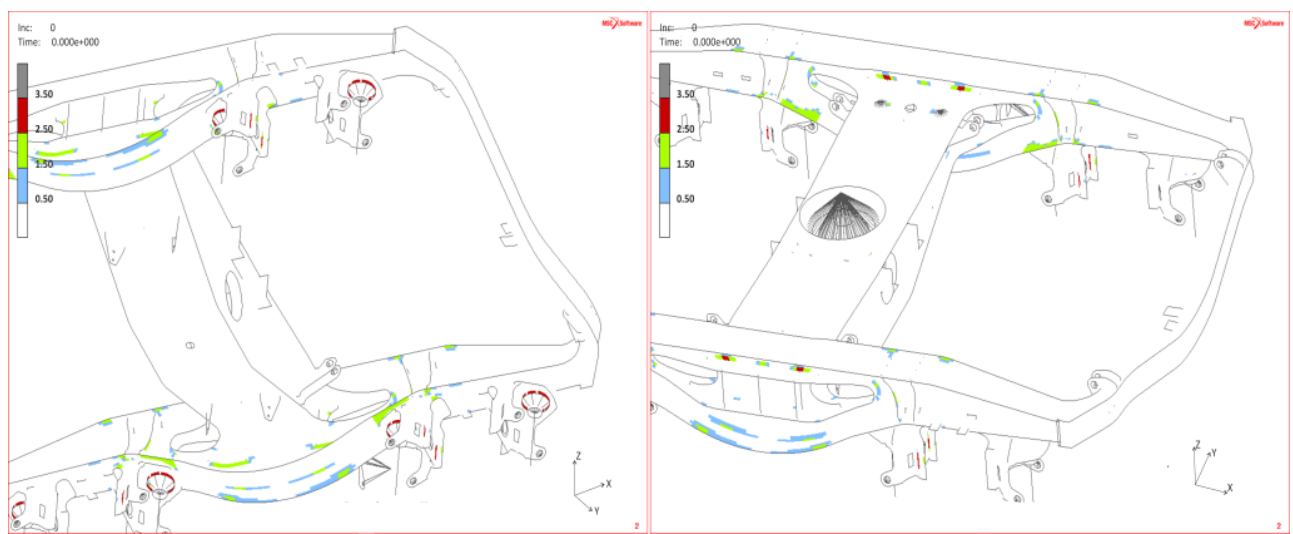

Fig. 8. Exceeded curve "al" (blue color) -longitudinal beam web 


\section{Conclusion}

Computational simulations are now an integral part of the development process of rolling stock. They allow a more detailed analysis of the behaviour of the vehicle as a whole or its individual parts. Therefore, it is possible to better optimize the design of rail vehicles and prevent potential problems in the operation, which would require increased costs. The bogies of rail vehicles are required to withstand the maximum loads consistent with their operational requirements and achieve the required service life under normal operating conditions with an adequate probability of survival.

Static and fatigue tests of bogie frame prototype (Fig. 9) have been performed in internationally accredited institution. The results of the measurements and the defectoscopic tests showed no deformations or cracks. Results of calculations and prototype tests prove, that new designed construction of the bogie frame satisfies strength conditions.

With this research and development subjects deals other publications too [5-12].

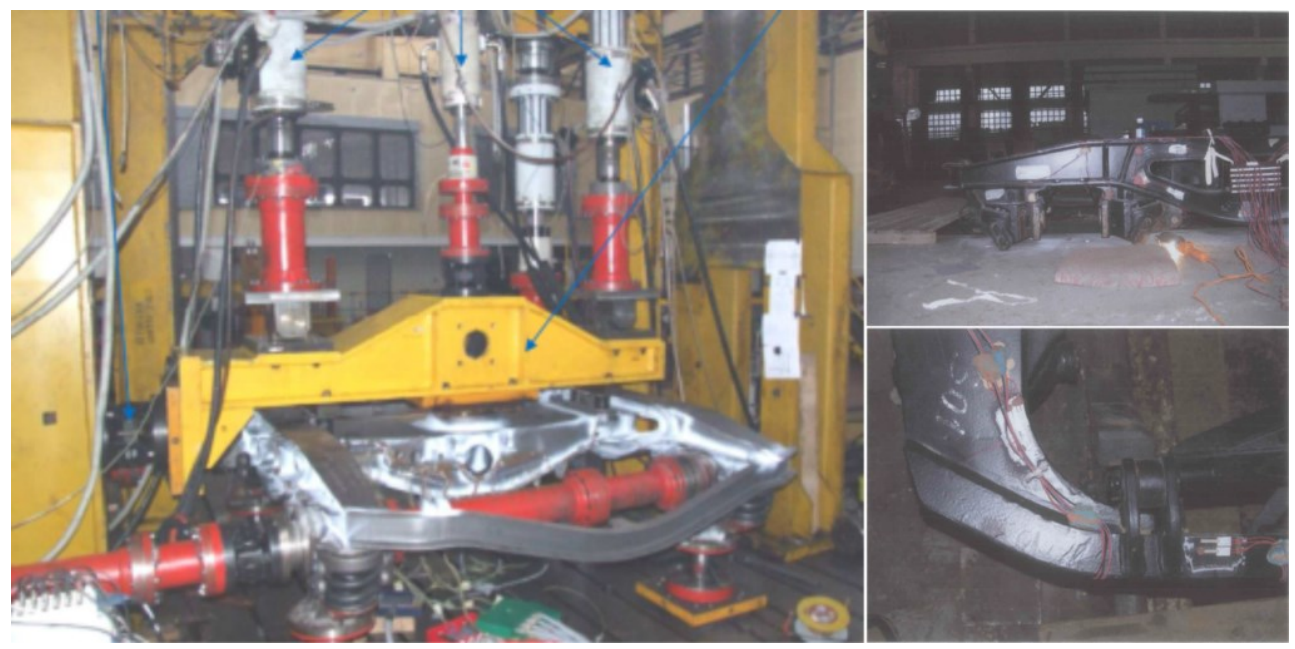

Fig. 9. Fatigue and strength tests of prototype bogie frame

This publication is the result of the project implementation Development of two types of freight wagons with bogies for non-standard wheelbase or track wheelset, complying with the criteria for interoperability, environmental issues, safety and reliability, ITMS 26220220070, supported by the Operational Programme Research and development funded by the ERDF.

The work was supported by the Cultural and Educational Grant Agency of the Ministry of Education of the Slovak Republic in project No. KEGA 077ŽU-4/2017: Modernization of the Vehicles and engines study program. The work was also supported by the project No. APVV-0842-11: Equivalent railway operation load simulator on the roller rig and VEGA Nr. 1/0927/15: Research of the use of alternative fuels and hybrid drives on traction vehicles with aim to reduce fuel consumption and air pollutants production.

Research-Educational Center of Rail Vehicles (VVCKV)

\section{References}

1. P. Čižík, 2-axle bogie according to line Y25 for freight wagons. Dynamical problems in rail vehicles 2016: Slovak - Polish scientific workshop: Žilina December $6^{\text {th }}$ and $7^{\text {th }}$, 2016, Slovak Republic: proceeding of the workshop, Žilina: University of Žilina, ISBN 978-80-554-1299-3, 146-154 (2016) 
2. ERRI B12/RP17, No. 8, Programme of Stresses to be carried out on Wagons with Steel Underframe and Body Structure. European Rail Research Institute (1996)

3. EN 13 749: Railway applications - Wheelsets and bogies - Method of specifying the structural requirements of bogie frames. European Committee for Standardization (2011)

4. Commission Decision 2006/861/EC (Annex J) of 28 July 2006 and Commission decision of 23 January 2009 amending Decisions 2006/861/EC and 2006/920/EC (2009)

5. J. Gerlici, T. Lack, J. Harušinec, Realistic simulation of railway operation on the RAILBCOT test stand. Applied mechanics and materials 486, 387-395 (2014)

6. J. Gerlici, T. Lack, J. Harušinec, The Test Stand Load Modulus Implementation for the Realistic Railway Operation in the Laboratory Conditions. Manufacturing technology: journal for science, research and production 13 (4), 444-449 (2013)

7. J. Gerlici, T. Lack, J. Harušinec, Contact geometry influence on the rail/wheel surface stress distribution. Procedia Engineering 2, Fatigue 2010: $10^{\text {th }}$ international fatigue congress: June 6-11, 2010 Prague, Czech Republic, (1), 2249-2257 (2010)

8. V. Hauser, et al., Impact of three axle boxes bogie to the tram behavior when passing curved track. Procedia Engineering 192, 295-300 (2017)

9. M. Kassner, Fatigue strength analysis of a welded railway vehicle structure by different methods. International Journal of Fatigue 34 (1), 103-111 (2012)

10. M. Sága, R. Bednár, M. Vaško, Contribution to modal and spectral interval finite element analysis. Vibration Problems ICOVP 2011, Springer Proceedings in Physics 139, 269-274 (2011)

11. A. Sapietová, M. Sága, P. Novák, R. Bednár, J. Dižo, Design and application of multisoftware platform for solving of mechanical multi-body system problems. Mechatronics: Recent technological and scientific advances, 345-354 (2011)

12. M. Svoboda, J. Soukup, Dynamic Measurement of Four-Axle Railway Wagon. Manufacturing technology: Journal for science, research and production 13 (4), 552-558 (2013) 